\title{
Addition of Phosphatases and Phytases to Mature Compost to Increase Available Phosphorus: A Short Study
}

\author{
Adrian Esteban Ortega-Torres (D), Enrique Rico-García *, Rosario Guzmán-Cruz (D), Irineo Torres-Pacheco, \\ Erik Gustavo Tovar-Pérez (D) and Ramón Gerardo Guevara-González (D) \\ Departamento de Biosistemas, Facultad de Ingeniería, Universidad Autónoma de Querétaro, \\ Querétaro C.P. 76010, Mexico; adrianesotorres@gmail.com (A.E.O.-T.); rosario.guzman@uaq.mx (R.G.-C.); \\ irineo.torres@uaq.mx (I.T.-P.); erikgtp@yahoo.com.mx (E.G.T.-P.); ramon.guevara@uaq.mx (R.G.G.-G.) \\ * Correspondence: ricog@uaq.mx; Tel.: +52-442-364-4443
}

Citation: Ortega-Torres, A.E.; Rico-García, E.; Guzmán-Cruz, R.; Torres-Pacheco, I.; Tovar-Pérez, E.G.; Guevara-González, R.G. Addition of Phosphatases and Phytases to Mature Compost to Increase Available Phosphorus: A Short Study. Agronomy 2021, 11, 2555. https:// doi.org/10.3390/agronomy11122555

Academic Editors: Othmane Merah, Purushothaman

Chirakkuzhyil Abhilash, Magdi T. Abdelhamid, Hailin Zhang and Bachar Zebib

Received: 15 November 2021 Accepted: 14 December 2021 Published: 16 December 2021

Publisher's Note: MDPI stays neutral with regard to jurisdictional claims in published maps and institutional affiliations.

Copyright: (c) 2021 by the authors. Licensee MDPI, Basel, Switzerland. This article is an open access article distributed under the terms and conditions of the Creative Commons Attribution (CC BY) license (https:// creativecommons.org/licenses/by/ $4.0 /)$.

\begin{abstract}
Agriculture depends on fertilizers to provide nutrients for plants. Phosphorus (P) is one of these nutrients and is the second-most necessary for plant growth. Global production of $P$ fertilizer is concentrated in Morocco, China and the United States. A large amounts of P resources are found in organic wastes that can be transformed through phosphate-solubilizing microorganisms during the composting process. In this study, we first determined the enzymatic activity of phosphatases and phytase from Pseudomonas aeruginosa ATC 15442. Second, we evaluated the mineralization of P in mature compost when inoculated with P. aeruginosa ATC 15442, phytases, a cocktail of phosphatesolubilizing enzymes and their combinations. Finally, we evaluated different concentrations of the cocktail trying to release more $P$ in the compost. The results indicated that $P$. aeruginosa exuded alkaline phosphatases, acid phosphatase, neutral phosphatase and phytase. The enzymatic cocktail increased inorganic P (Pi) when added to the mature compost: this was able to release up to $95 \%$ more $\mathrm{Pi}$ in the compost compared to the amount of Pi released in the control compost. The current study demonstrated the importance of adding the cocktail to enhance Pi in mature compost; however, further studies are required to confirm the results and practical applications.
\end{abstract}

Keywords: enzymes; agriculture; organic wastes; nutrients; phosphate-solubilizing bacteria

\section{Introduction}

Phosphate rock deposits provide Phosphorus $(\mathrm{P})$ to the world, and scarcity of these rocks is predicted by the middle or end of the century [1]. This indicates that phosphate rock is decreasing in quantity and increasing in cost, which raises phosphate fertilizer prices for agriculture [1,2]. For food safety, this outlook is not hopeful, as this may compromise agriculture in the near future [3,4]. Plants are the basis of the global food supply and are the only ones that absorb and integrate $P$ from rock into the food chain [2].

Faced with this challenge, an alternative is found in organic wastes that are unsustainably disposed of in open dumps. Organic wastes that are poorly disposed could generate nutrients when properly treated [5]. Waste conversion into beneficial materials is important for recycling and recovery. It can provide nutrients for plant growth from organic wastes and soil improvers, such as in the case of $\mathrm{P}$, which would alleviate the global dependence on phosphate rock [6]. Currently, it has been estimated that $40 \%$ of $\mathrm{P}$ absorbed by plants worldwide comes from organic waste decomposition in soil $[7,8]$.

An ecological, economical and practical way to recycle organic $\mathrm{P}(\mathrm{Po})$ in wastes is through composting; however, composting generates low conversion rates of Po into inorganic $\mathrm{P}(\mathrm{Pi})$. One way to increase $\mathrm{Pi}$ in compost is to add phosphate-solubilizing microorganisms (PSM) [7]. However, they compete with native microorganisms; other times, abiotic conditions are not favorable to them, or even a small change in the compost mixture may reduce its effectiveness, resulting in Po not being converted into Pi [8]. In this case, the general biochemical route by which PSM convert Po into Pi involves extracellular 
enzymes [9], and the addition of these enzymes can avoid the biotic and abiotic competition of PSM to increase Pi in compost.

Enzymes degrade wastes due to their capacity to solubilize substrates [10]. A single enzyme only acts on a particular substrate; compost is a combination of many substrates containing different Po compounds, such as proteins, nucleic acids, phospholipids and phytic acid, and thus a combination of enzymes is needed to increase Pi in compost [11]. Po conversion is achieved by alkaline phosphatase, neutral phosphatase and acid phosphatase, which catalyze compounds such as phosphate monoesters or diesters, polyphosphates and phosphonates present in different forms in the residues. Phytases convert the Po of phytic acid that exists in large quantities in the feces of ruminants because it is the largest reservoir of $P$ in vegetables [11-15].Nevertheless, there is little information on the application of enzymes in the composting process for the degradation and/or conversion of nutrients [16,17]. A report of the application of phytase on a potted Malus hupehensis yielded an increased phosphatase activity and Pi in the potted substrate [18]. Feng et al. [8] reported the application of enzymes in compost; ligninolytics were applied, increasing the degradation rate of lignin and hemicellulose by $5.24 \%$ and $11.74 \%$, respectively, compared to the control. The use of enzymes from microorganisms in vitro is applied as pretreatments in organic solid waste, a culture of Aspergillus niger in anaerobic fermentation was used to provide an enzymatic pretreatment for agro-industrial products, which was shown to yield a better performance of 3.2-3.6 times more methane than the control [19].According to this the following hypothesis is stated. The addition of phosphate-solubilizing enzymes on mature compost will increase Pi compared to conventional composting.

The aims of this study were to (1) evaluate the enzymatic activity of alkaline phosphatase, neutral phosphatase, acid phosphatase and phytase of a P. aeruginosa culture in potato dextrose broth (PDB) selected to allow further commercial scale because their main components are easy available, (2) study the addition to mature compost of P. aeruginosa and the enzymatic cocktail produced from the PDB culture and (3) identify enzymatic treatments to increase $\mathrm{Pi}$ in mature compost.

\section{Materials and Methods}

\subsection{Bacterial Culture and Enzyme Determination}

PSB Pseudomonas aeruginosa ATC 15442, kindly provided by the National Polytechnic Institute from Querétaro, México. P. aeruginosa ATC 15442 was activated by incubation in LB media to $24 \mathrm{~h}$. The activated bacteria were inoculated in selective media ( $\mathrm{p}$-nitrophenol phosphate NBRIP (SYGMA-ALDRICH Co., St Louis, MO, USA) and phytase production medium (SYGMA-ALDRICH Co., St Louis, MO, USA) designed to confirm the presence of phytases and of alkaline, acid and neutral phosphatases in the culture according to a previous report by Tabatai and Bremner [20]. Once the presence of the enzymes was confirmed, liquid cultures were established under the following conditions: phytase production medium (PHY) containing sodium phytate [14] and potato dextrose broth, PDB, (MCD LAB S.A. de C.V., Oaxaca, México) were inoculated with activated P. aeruginosa ATC 15442 and incubated on an orbital shaker $(4300 \mathrm{~W})$ at $200 \mathrm{rpm}$ and $30^{\circ} \mathrm{C}$. Growth was monitored by optical density with a spectrophotometer to $16 \mathrm{~h}$ and a cfu/g count on solid phytic medium PHY and PDA by the most probable number method.

The cultures were centrifuged at the maximum point of the exponential phase $(9 \mathrm{~h})$ at $5000 \mathrm{rpm}$ to $5 \mathrm{~min}$, and the supernatant was used for enzymatic activity assays as described below.

Phytase enzymatic activity was determined by measuring the amount of phosphate released from PHY during the enzymatic reaction avoiding the addition of ammonium molybdate to stop the reaction [14].

The supernatant was also evaluated for phosphatase activity by the method outlined by Tabatabai and Bremmner [20]. One milliliter of supernatant was measured at $420 \mathrm{~nm}$ using a UV-Vis spectrophotometer (SP-UV 1100, DLAB) to determine Pi. A standard p-nitrophenol curve was used to determine the enzyme unit [15]. One unit (U) of en- 
zyme was defined as the amount of the enzyme required to produce $1 \mu \mathrm{mol}$ of inorganic orthophosphate per milliliter per minute under assay conditions.

Protein content was determined by Bradford's method [21]. One enzymatic activity unit (U) expressed as $\mathrm{U}$ per $\mathrm{mg}$ of protein ( $\mathrm{U} / \mathrm{mg}$ protein).

All treatments were set up in triplicate. The supernatant solution was used as a crude enzyme for further analysis [8].

\subsection{Composting Preparation}

Samples of mature cow manure compost were obtained from the Universidad Autónoma de Querétaro, Mexico

The physicochemical composition of the compost used is described in Table 1. In the laboratory, stones and different materials were separated from the compost. Then, the material was sifted in a mesh of $0.29 \mathrm{~mm}$ to obtain a homogenized mixture. The compost samples used were $50 \mathrm{~g}$ for each experiment.

Table 1. Enzymes and bacteria combinations of P. aeruginosa ATC 15442 on the compost.

\begin{tabular}{cc}
\hline Physicochemical Composition & Values (\%) \\
\hline Total nitrogen & 1.955 \\
Total phosphorus & 0.790 \\
Carbon/nitrogen ratio & 3.298 \\
Organic matter & 11.158 \\
Moisture content & 77.767 \\
Ashes & 11.165 \\
\hline
\end{tabular}

\subsection{Assesment of Phosphate-Solubilizing Activity of Enzymes, Bacteria and Combinations to} Increase Pi on Mature Compost

The experiment consisted of increasing the moisture content in the compost to saturation with phosphate-solubilizing treatments at a ratio of 1:1 volume/weight (compost). The compost was spread in a plate to obtain a uniform thickness, a $10 \%$ volume of each phosphate-solubilization treatment was applied, and the volume was complemented with deionized water. The treatments of phytase, phosphate-solubilizing enzyme, bacteria and their combinations were evaluated at $10 \%$ of phosphate-solubilizing activity according to the increment of the established percentages of PSB inoculation [8,22]. On the other hand, this is one of the first evaluations to increase Pi in mature compost at $24-72 \mathrm{~h}$.

The treatments are described in Table 2. A control group was established by adding deionized water.

Table 2. Phosphate-solubilizing combination of P. aeruginosa ATC 15442 applied on mature compost.

\begin{tabular}{cc}
\hline Treatment Code & Description-Composition \\
\hline PhoEnz & Enzymatic cocktail with phytases and alkaline, acid and neutral \\
phosphatases on PDB \\
P. aeruginosa & P. aeruginosa ATC15442 as phosphate-solubilizing bacteria on \\
Phy & PDB \\
PhoEnz + P. aeruginosa & Phytases on PHY \\
PhoEnz + P. aeruginosa + Phy & Combination of $5 \%$ and $5 \%$ \\
W & Combination of $3.3 \%, 3.3 \%$ and $3.3 \%$ \\
Deinoized water (control group)
\end{tabular}

Compost triplicate samples were obtained at 24,48 and $72 \mathrm{~h}$ to quantify Pi by the Olsen method. The Total $\mathrm{P}$ was determined by digestion in nitric acid. Pi values were reported as percentages of Total $P$. 


\subsection{Assesment of PhoEnz in Higher Percentages to Increase Pi on Mature Compost}

PhoEnz at $24 \mathrm{~h}$ had the highest conversion of Po into Pi, and thus it was selected for a second experiment, in which only the percentages of PhoEnz were increased. In this experiment, the compost was prepared as outlined above. PhoEnz was added at 20, 40, 60, 80 and $100 \%$ at a ratio of $1: 1$ volume/weight (compost). There was also a control group (W) and the inactivation (InacPho) of phosphate solubilizing enzymes was carried out in the same volumes by heating the enzymes at $95^{\circ} \mathrm{C}$ for $25 \mathrm{~min}$. Compost triplicate samples were quantified for Pi by the Olsen method and for total $\mathrm{P}$ by digestion in nitric acid.

\subsection{Statistical Analysis}

Data were subjected to statistical analysis using S Statgraphics Plus, version 5.1 (1992). The effects of the experimental factors studied were determined by one-way analysis of variance (ANOVA). Mean comparisons were carried out by the Tukey $(p<0.05)$ test. The experimental designs for bacterial culture and enzyme determination were completely random, and for each phosphate-solubilizing assay conducted on compost, they followed an incomplete factorial design.

\section{Results}

\subsection{Bacterial Count and Specific Activity}

The abundance of culturable P. aeruginosa ATC 15442 on PHY medium was $1 \times 10^{7} \mathrm{cfu} / \mathrm{g}$, and the average phytase enzymatic activity was $0.113 \mathrm{U} / \mathrm{mg}$ protein. On PDB medium, the abundance of P. aeruginosa ATC 15442 was $1 \times 10^{8} \mathrm{cfu} / \mathrm{g}$, and the values for enzymatic activity are presented in Table 3.

Table 3. Enzymatic activity of P. aeruginosa ATC15442 on PDB. Values $( \pm)$ represent the standard deviation.

\begin{tabular}{cc}
\hline Enzyme Type & Average Enzymatic Activity (UmgProtein) \\
\hline Alkaline phosphatase & $0.242 \pm 0.0086$ \\
Acid phosphatase & $0.259 \pm 0.0098$ \\
Neutral phosphatase & $0.161 \pm 0.0072$ \\
Phytase & $0.005 \pm 0.0003$ \\
\hline
\end{tabular}

\subsection{Phosphate-Solubilizing Activity ofEnzymes, Bacteria and Combination to Mature Compost}

The phosphate-solubilizing activity of different treatments was evaluated by measuring Pi in mature compost. PhoEnz treatments showed an increment in Pi presence compared with all the treatments and 20\% compared to W. Interestingly, treatments PhoEnz + P. aeruginosa and PhoEnz + P. aeruginosa + Phy showed no difference from $\mathrm{W}$ which suggests interference between enzymes and the bacteria, on the other hand, treatment Phy 72 showed a Pi increment, which is only enzymes (Figure 1).

\subsection{PhoEnz in Higher Percentages to Increase Pi on Mature Compost}

The phosphate-solubilizing enzymatic cocktail (PhoEnz) was increased on percentages to raise Pi on mature compost. The PhoEnz treatment's percentage increases were not proportional to Pi release. PhoEnz treatments at 20,40, and 60\% showed the highest Pi release, on other hand, PhoEnz 80 and 100\% led to a drastic drop in Pi release.

InacPho treatments showed no significant difference between them, but Pi was higher than W.

PhoEnz $40 \%$ had $12.55 \%$ Pi release on mature compost, however we had a large quantity of Total P retained in compost, which represents $87.45 \%$ (Figure 2). 


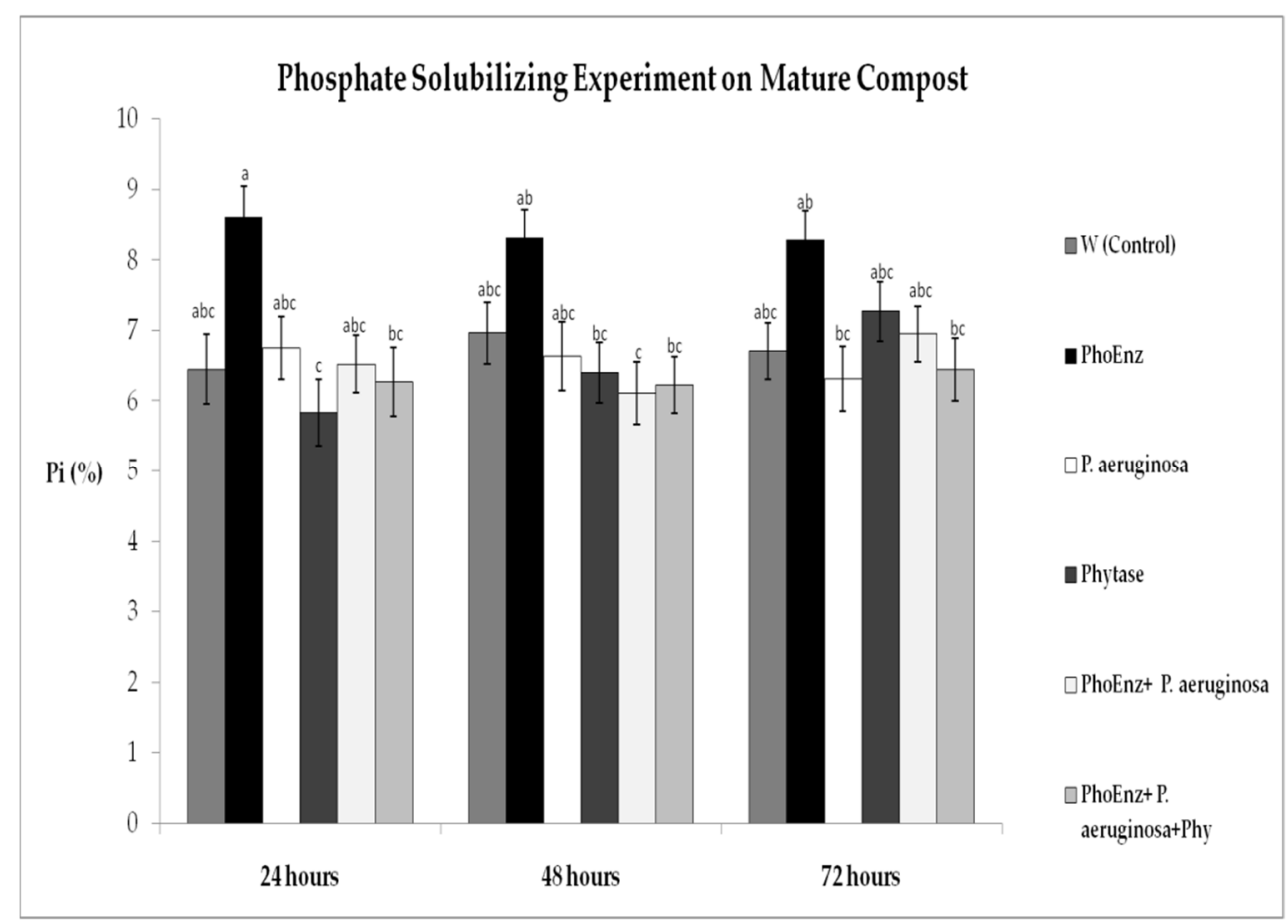

Figure 1. Pi obtained by phosphate-solubilizing combination of P. aeruginosa ATC 15442 applied on mature compost. Different letters in each column indicate significant differences according to Tukey's test $(p<0.05)$. Error bars are the standard deviation.

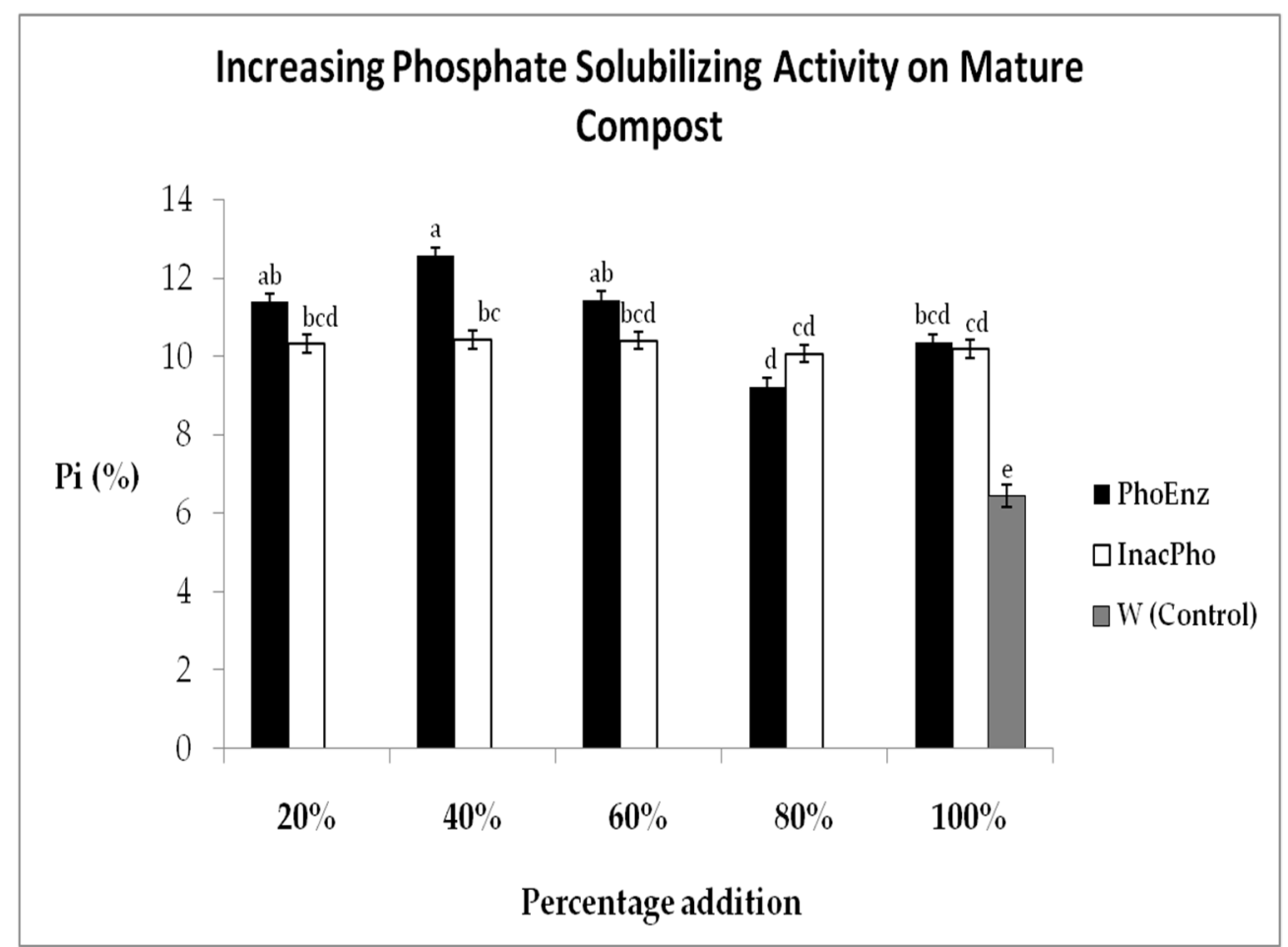

Figure 2. Pi obtained by phosphate-solubilizing enzymatic cocktail and inactivated cocktail applied on mature compost. Different letters in each column indicate significant differences according to Tukey's test $(p<0.05)$. Error bars are the standard deviation.

\section{Discussion}

The present work is one of the first to report the addition of PSB, phytases and phosphatases aiming the increase of $\mathrm{Pi}$ in mature cow manure compost. Differences 
have arisen between the different treatments with high Po conversion with this proposed technology compared to traditional compost.

In soil, $\mathrm{P}$ is present in different chemical forms such as $\mathrm{Pi}$ available for plants or microorganisms, the immobilized P is solubilized through organic acids exudated by PSM; and the Po is mineralized through enzymes exudated by PSM. Once the immobilized $\mathrm{P}$ and Po have been solubilized, $\mathrm{P}$ becomes Pi. Po has been reported to be present in several organic forms in manure compost such as phytic acid, phospholipids and nucleic acids [23-25]. These molecules are substrates for enzymatic activity specially phytic acids represent about the $80 \%$ of organic waste; however, their links are very difficult to break. Phytases are the only enzymes that convert Po present in phytic acid into Pi. On the other hand, phosphatases manage the convertion of the other biological forms of Po [4].

The mechanism by which phytases and phosphatases mineralize Po depend mainly on the presence of the organic forms, working as enzymatic substrates. As we know, most of the organic wastes and therefore, compost processes contain phytic acid, phospholipids and nucleic acids, suggesting that this Pi release mechanism is suitable through compost processes with different organic matter sources.

According to the literature, researchers have focused on increasing Pi by the inoculation of PSB or the addition of inorganic fertilizers directly into compost. Although the inoculation of bacterial strains in soil or compost has been reported as an efficient, environmentally friendly and viable approach [26]. Direct inoculation of bacteria in compost or soil led to competition with endogenous microorganisms and poor adaptation of laboratory-cultivated microorganisms to environmental conditions, results in decreasing concentration of the inoculated bacteria as reported previously [27].

As an alternative to the inoculation of bacteria in compost, we evaluated the addition of an enzymatic cocktail in order to increase Pi. Our first results indicate an increase in $20 \%$ of the content of Pi in the compost treated with the enzymatic cocktail compared to treatment where the bacterial culture was directly inoculated.

Focusing on the phosphate-solubilizing enzymes, bacteria from different genera have been evaluated by their genetic and metabolic capacity to produce specific enzymes. Behera et al. [15] identified an acid phosphatase concentration of 76.8 U/Ml in a Serratia sp. culture. Later, Ghorbanzadeh et al. [28] found alkaline phosphatase activity in a soil combined with pomace inoculated with Pseudomonas [29]. These results are in accordance with earlier results where inoculated Bacillus sp. MQH-19 produced phytases and achieved an increase of $8-13 \%$ in Pi in cattle manure [12]. Since phosphate solubilization may be achieved by several different enzymes, in the present study, we evaluated for the first time, in our knowledge, four different phosphate-solubilizing enzymes within a single bacterium.

Another important factor in this approach is the culture media for inoculated bacteria, which for the obtention of enzymes, the medium where each bacterium is culturedseems to be a fundamental factor for phosphate-solubilizing enzyme production and activity. It has been reported that Pseudomonas kilonensis PK11 had a higher phosphatase activity at pH 6.5 in presence of the nanocarriers nanoclay and alginate [7]. Here, we report an activation of phosphate-solubilizing activity from different exudated enzymes including phytases, acid, neutral and alkaline phosphatases by P. aeruginosa ATC 15442 cultured in commercial potato dextrose broth. This result may indicate a genetic or metabolic triggered by a specific component of PDB.

This is one of the first reports on the addition of an enzymatic cocktail for Po release in composting, which revealed a significant increase in Pi. Enzyme cocktail treatment offers several advantages, mainly due to the easy reproduction of $P$. aeruginosa grown and low cost of the basic components of PDB.

The addition of the phosphate-solubilizing enzymatic cocktail to compost, according to our results, allows to increase Pi by $94.8 \%$ compared to conventional composting process, the treatment that achieve this percentage was PhoEnz $40 \%$ which released $12.56 \%$ Pi compared to control $\mathrm{W}$ which released $6.45 \% \mathrm{Pi}$ and PSB P. aeruginosa ATC1544521 addition which released $6.27 \% \mathrm{Pi}$. These results and findingsindicatethatphosphate- 
solubilizingenzymaticcocktailisimportantforthe Pi released on mature compost where all the phosphatase and phytase activity from endogenous PSB has already happened.

Interestingly, treatments consisting of the addition of a heat-inactivated enzymatic cocktail showed statistical differences with control treatments, suggesting that the same component of the media that activated a phosphate-solubilizing enzymes production in P. aeruginosa, activated the production on compost endogenous bacteria. However, active enzymes generated statistical differences compared to inactive enzymes.

This is a post-composting procedure evaluated in a compost from cow manure. Results should be evaluated in composts with different organic matter as raw material and different physico-chemical properties such as $\mathrm{pH}$ and presence of cations and anions. The enzymes phosphatase (acid, neutral and alkaline) and phytase obtained from microorganism culture under controlled conditions may be suitable for use on an industrial scale.

\section{Conclusions}

A 94.8\% Pi increase was obtained on mature compost with the addition of phosphatesolubilizing enzyme cocktail compared with traditional composting. This was a pilot short study which represents an alternative to $\mathrm{P}$ transformation during composting; however, we only released $12.7 \%$ of Total $P$ hence further research is required to validate the study. To our knowledge, this is one of the first reports to evaluated phosphate-solubilizing enzymatic activities in a Pseudomonas aeruginosa PDB culture, and the joint addition of acid phosphatase, neutral phosphatase, alkaline phosphatase and phytase on mature compost. The phosphate-solubilizing enzymatic cocktail has the advantage of increasing Pi on mature compost acting directly over Po substrate avoiding the competence between native and exogenous microorganisms on the compost. We think that the enzymatic cocktail methodology could be used successfully in the same manner in other sources of compost. The use of PDB needs further investigations to confirm real scale production and the final product needs to be evaluated on agriculture.

Author Contributions: A.E.O.-T.: Conceptualization, Data curation, Formal analysis, Investigation, Methodology, Software, Visualization, Writing-original draft. E.R.-G.: Funding acquisition, Project administration, Resources, Supervision. R.G.-C.: Contribution to interpretation of data. I.T.-P.: Experimental Design, Supervision and Data Validation. E.G.T.-P.: substantial contribution to the conception or design of the work. R.G.G.-G.: Investigation and accountable for integrity of any part of the work are appropriately investigated and resolved. All authors have read and agreed to the published version of the manuscript.

Funding: This research was funded by Universidad Autónoma de Querétaro, FOFI-UAQ-2018 DPI-464/2018.

Acknowledgments: The authors are grateful to the Universidad Autónoma de Queretaro for providing laboratory facilities and resources to carry out this study. To CONACYT for its support and Instituto Politécnico Nacional for the confidence to use the bacteria of this research.

Conflicts of Interest: The authors declare no conflict of interest.

\section{References}

1. Cordell, D.; Neset, T.S.S. Phosphorus vulnerability: A qualitative framework for assessing the vulnerability of national and regional food systems to the multi-dimensional stressors of phosphorus scarcity. Glob. Environ. Chang. 2014, 24, 108-122. [CrossRef]

2. Rittmann, B.E.; Mayer, B.; Westerhof, P.; Edwards, M. Capturing the lost phosphorus. Chemosphere 2011, 84, 846-853. [CrossRef]

3. Childers, D.; Corman, J.; Edwards, M.; Elser, J.J. Sustainability challenges of phosphorus and food: Solutions from closing the human phosphorus cycle. BioScience 2011, 61, 117-124. [CrossRef]

4. Wei, Y.; Wei, Z.; Cao, Z.; Zhao, Y.; Zhao, X.; Lu, Q.; Wang, X.; Zhang, X. A regulating method for the distribution of phosphorus fractions based on environmental parameters related to the key phosphate-solubilizing bacteria during composting. Bioresour. Technol. 2016, 211, 610-617. [CrossRef]

5. Salleh, M.A.M.; Mahmoud, D.K.; Karim, W.A.; Idiris, A. Cationic and anionic dye adsorption by agricultural solidwastes: A comprehensive review. Desalination 2011, 280, 1-13. [CrossRef] 
6. Owen, D.; Williams, A.P.; Griffith, G.W.; Withers, P.J.A. Use of commercial bio-inoculants to increase agricultural production through improved phosphorus acquisition. Appl. Soil Ecol. 2015, 86, 41-54. [CrossRef]

7. Safari, M.; Motamedi, E.; Kari, A.S.; Modarres, M. Nano-carriers effects on the viability and ef fi ciency of Pseudomonas strains as phosphate solubilizing bacteria. Heliyon 2020, 6, e05076. [CrossRef]

8. Feng, C.; Zeng, G.; Huang, D.; Hu, S.; Zhao, M.; Lai, C.; Huang, C.; Wei, Z.; Li, N. Effect of ligninolytic enzymes on lignin degradation and carbon utilization during lignocellulosic waste composting. Process. Biochem. 2011, 46, 1515-1520. [CrossRef]

9. Frossard, E.; Achat, D.L.; Bernasconi, S.M.; Bünemann, E.S.; Fardeau, J.-C.; Jansa, J.; Morel, C.; Rabeharisoa, L.; Randriamanantsoa, L.; Sinaj, S.; et al. The Use of Tracers to Investigate Phosphate Cycling in Soil-Plant Systems. In Phosphorus in Action, Soil Biology; Bunemann, E.K., Oberson, A., Frossard, E., Eds.; Springer: Berlin/Heidelberg, Germany, 2011; Volume 26. [CrossRef]

10. Kumar, A.; Chandra, R. Ligninolytic enzymes and its mechanisms for degradation of lignocellulosic waste in environment. Heliyon 2020, 6, e0317. [CrossRef] [PubMed]

11. Menez-Blackburn, D.; Inostroza, N.G.; Gianfreda, L.; Greiner, R.; Mora, M.L.; Jorquera, M.A. Phytase-producing Bacillus sp. inoculation increases phosphorus availability in cattle manure. J. Soil Sci. Plant Nutr. 2016, 16, 200-210. [CrossRef]

12. Zhao, X.; He, X.; Xi, B.; Gao, R.; Tan, W.; Zhang, H.; Li, D. The evolution of water extractable organic matter and its association with microbial community dynamics during municipal solid waste composting. Waste Manag. 2016, 56, 79-87. [CrossRef]

13. Turner, B.L.; Engelbrecht, B.M.J. Soil organic phosphorus in lowland tropical rain forests. Biogeochemistry 2011, 103, 297-315. [CrossRef]

14. Rocky-salimi, K.; Hashemi, M.; Safari, M. A novel phytase characterized by thermostability and high pH tolerance from rice phyllosphere isolated Bacillus subtilis BS 46. J. Adv. Res. 2016, 7, 381-390. [CrossRef]

15. Behera, B.C.; Yadav, H.; Singh, S.K.; Mishra, R.R.; Sethi, B.K.; Dutta, S.K.; Thaoi, H.N. Phosphate solubilization and acid phosphatase activity of Serratiasp.isolated from mangrove soil of Mahanadi river delta, Odisha, India. J. Genet. Eng. Biotechnol. 2017, 15, 169-178. [CrossRef] [PubMed]

16. Yu, X.; Liu, X.; Zhu, T.H.; Liu, G.H.; Mao, C. Co-inoculation with phosphate-solubilizing and nitrogen-fixing bacteria on solubilization of rock phosphate and their effect on growth promotion and nutrient uptake by walnut. Eur. J. Soil Biol. 2012, 50, 112-117. [CrossRef]

17. Datta, A.; Gujre, N.; Gupta, D.; Agnihotri, R.; Mitra, S. Application of enzymes as a diagnostic tool for soils as affected by municipal solid wastes. J. Environ. Manag. 2021, 286, 112169. [CrossRef] [PubMed]

18. Xiang, C.Y.; Ma, Y.M.; Tian, X.P. Effects of long-term culture and fertilization on the contents of forms of phosphorus and their availability in albic soil. Acta Agron. Sin. 2005, 31, 48-52.

19. Mlaik, N.; Khoufi, S.; Hamza, M.; Masmoudi, M.A.; Sayadi, S. Enzymatic pre-hydrolysis of organic fraction of municipal solid waste to enhance anaerobic digestion. Biomass Bioenergy 2019, 127, 105286. [CrossRef]

20. Tabatai, M.A.; Bremner, J.M. Use of p-nitrophenyl phosphate for assay of soil phosphatase activity. Soil Biol. Biochem. 1969, 1, 301-307. [CrossRef]

21. Bradford, M.M. A rapid and sensitive method for the quantitation of microgram quantities of protein utilizing the principle of protein-dye binding. Anal. Biochem. 1976, 72, 248-254. [CrossRef]

22. Paratesh, F.; Alikhani, H.A.; Etesami, H. Vermicomposting enriched with phosphate-solubilizing bacteria provides plant with enough phosphorus in a sequential cropping under calcareous soil conditions. J. Clean. Prod. 2019, 221, 27-37. [CrossRef]

23. Nash, D.M.; Haygarth, P.M.; Turner, B.L.; Condron, L.M.; McDowell, R.W.; Richardson, A.E.; Watkins, M.; Heaven, M.W. Using organic phosphorus to sustain pasture productivity: A perspective. Geoderma 2014, 221-222, 11-19. [CrossRef]

24. Annaheim, K.E.; Doolette, A.L.; Smernik, R.J.; Mayer, J.; Oberson, A.; Frossard, E.; Bünemann, E.K. Long-term addition of organic fertilizers has little effect on soil organic phosphorus as characterized by ${ }^{31} \mathrm{P}$ NMR spectroscopy and enzyme additions. Geoderma 2015, 257-258, 67-77. [CrossRef]

25. Torres, I.F.; Bastida, F.; Hernández, T.; García, C. The effects of fresh and stabilized pruning wastes on the biomass, structure and activity of the soil microbial community in a semiarid climate. Appl. Soil Ecol. 2015, 89, 1-9. [CrossRef]

26. Tyagi, M.; da Fonseca, M.M.R.; de Carvalho, C.C.C.R. Bioaugmentation and biostimulation strategies to improve the effectiveness of bioremediation processes. Biodegradation 2011, 22, 231-241. [CrossRef]

27. Masy, T.; Demanèche, S.; Tromme, O.; Thonart, P.; Jacques, P.; Hiligsmann, S.; Vogel, T.M. Hydrocarbon biostimulation and bioaugmentation in organic carbon and clay-rich soils. Soil Biol. Biochem. 2016, 99, 66-74. [CrossRef]

28. Ghorbanzadeh, N.; Mahsefat, M.; Farhangi, M.B.; Rad, M.K.; Proietti, P. Short-term impacts of pomace application and Pseudomonas bacteria on soil available phosphorus. Biocatal. Agric. Biotechnol. 2020, 28, 101742. [CrossRef]

29. Martínez-Salgado, M.M.; Blu, R.O.; Janssens, M.; Fincheira, P. Grape pomace compost as a source of organic matter: Evolution of quality parameters to evaluate maturity and stability. J. Clean. Prod. 2019, 216, 56-63. [CrossRef] 